\title{
乱流境界層における対数速度分布に及ぼす逆圧力勾配の影響
}

\section{Effect of Adverse Pressure Gradients on the Log-law in Turbulent Boundary Layers}

\author{
O正 望月信介（山口大エ）准 太田圭亮（京セラ） \\ 正 亀田孝嗣（山口大工） 正 大坂英雄（山口大エ）
}

\author{
Shinsuke MOCHIZUKI, Yamaguchi University, 2-16-1 Tokiwadai, Ube 755-8611, JAPAN \\ Keisuke OHTA, Kyoto ceramics Co. Ltd., Fushimiku, Kyoto, 612-8501, JAPAN \\ Takatsugu KAMEDA, Yamaguchi University \\ Hideo OSAKA, Yamaguchi University
}

Key Words: Turbulence, Boundary layer, Log-law, Adverse Pressure Gradient

\section{1. 緒 言}

逆圧力勾配下に発達する境界層はディフューザ内部や流 体機械内あるいは翼面上などでみられ，工学上極めて重要な 流れ場である。この流れ場の予測と制御には精密な実験によ り取得されたデータとそれに基づく普遍性の高い相似性の 確立が不可欠といえる.

乱流境界層における実験データの取得に関して, 零圧力勾 配下における相似性の議論においてさえ，以下の注意を払う べきことが推奨されている．1．運動量厚さに基づくレイノ ルズ数は $R_{\theta}>10,000$ であること，2. 壁面せん断忘力と平均速 度は独立に計測すべきこと，3.法則の妥当性を見極めるには 摩擦速度で無次元化した平均速度の不確かさが $1 \sim 2 \%$ 以内 であること，4.平均速度勾配が高精度に算出できるよう考慮 されていること, $\mathbf{5}$ さらに可能な限り高次の統計量の取得が なされていること，等である。これに加え，逆圧力勾配下に おいては層の発達が早まるため, 良好な二次元性を保つこと および外層構造の非平衡性の影響を避けることがあげられ る.

本実験においては, $R_{\theta}=10,200$ の十分に高いレイノルズ数 の乱流境界層を作成するとともに以下の項目を付加した．主 流速度の変化を平衡境界層成立に要求される設定とする。ま た，壁面せん断応力は新しく開発する直接測定により計測す る, 二次元性の評価には厳密な運動量積分方程式を採用する, ことである。これらの事柄に注意を払った実験に基づき，逆 圧力勾配下にお゙ける対数法則の妥当性を吟味し, 必要であれ ばその修正を行うことを目的とする。

\section{2. 実験結果}

壁領域において速度の尺度を下式のように定義する．

$$
u_{*} \equiv u_{\tau} \sqrt{1+\alpha p^{+} y^{+}}
$$

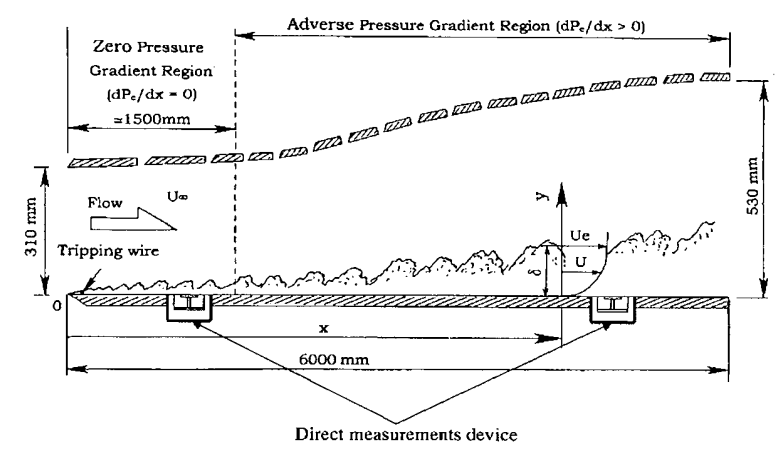

Fig.1 Schematic of flow field, coordinate system and nomenclature $p^{+} \equiv\left(v / u_{\tau}^{3}\right) d P_{e} / d x$, 係数 $\alpha$ は運動方程式において慣性項の 圧力勾配項に対する比率である. 本実験の場合 $\alpha=0.4$ の值を とる. 速度の尺度を $u_{*}$, 長さの尺度を壁からの距離 $y$ とし, 壁領域において平均速度勾配に下式が成立するものとする。 $\partial U / \partial y=u_{*} /(\kappa y)$

この尺度法則を積分することにより平均速度分布の関係式 (3)が得られる.

$$
U^{+}=\frac{1}{\kappa} \ln y^{+}+C-\frac{2}{\kappa} \ln \left(\frac{1+\sqrt{1+\alpha p^{+} y^{+}}}{2}\right)+\frac{2}{\kappa}\left(\sqrt{1+\alpha p^{+} y^{+}}-1\right)
$$

$\kappa=0.43, C=4.9$ および $\alpha=0.4$ として描いた式(3)の平均速度分 布を実験結果と比較し, 図 2 に示した。壁領域において (3) 式と実験データが良好に一致していることが分かる。

\section{3.結 言}

1. 直接測定により得られた局所壁面摩擦抵抗係数はプレ ストン管およびLudwieg-Tillmannによる值と $5 \%$ 程度の 差異を示した。

2. 逆圧力勾配下の壁領域における運動方程式の釣合いに おいて慣性項の影響は無視できない。したがって，壁 領域における平行流近似は妥当ではない.

3. 壁領域における速度の尺度の決定には圧力勾配と慣性 項の寄与を考慮する必要がある。それにより，速度の 尺度は $u_{*} \equiv u_{\tau} \sqrt{1+\alpha p^{+} y^{+}}$と定義できる。

4. 速度の尺度 $u_{*}$ と長さの尺度 $y$ を用いて平均速度勾配の 尺度法則を定義し，平均速度分布を導いた。導かれた 平均速度分布は実験データと良好に一致した。

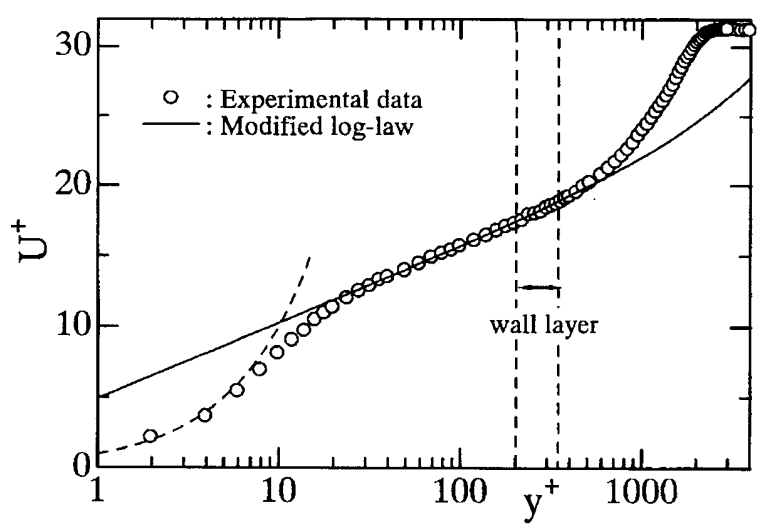

Fig. 2 Comparison between the modified lag-law calculated by Eq.(3) and experimental data. 